\title{
Acute and Subacute Toxicity Profile of Asparagus racemosus root extract, Isoprinosine and Shatvari Syrup in Swiss Albino Mice
}

\author{
B. Satheesh Kumar Bhandary ${ }^{1 *}$, K. P. Sharmila ${ }^{2}$, N. Suchetha Kumari ${ }^{3}$, Vadisha S. Bhat ${ }^{1}$, Ronald Fernandes ${ }^{4}$ \\ ${ }^{1}$ Department of ENT, ${ }^{2}$ Central Research Laboratory, ${ }^{3}$ Department of Biochemistry, K. S.Hegde Medical Academy, Nitte University, Mangalore, Karnataka, \\ India. ${ }^{4}$ Department of Pharmaceutical Chemistry, NGSM Institute of Pharma Sciences, Nitte University, Paneer, Deralakatte, Mangalore, Karnataka, India.
}

\section{ARTICLE INFO \\ Article history: \\ Received on: 21/10/2016 \\ Accepted on: 24/01/2017 \\ Available online: 30/05/2017}

\section{Key words:}

Acute, subacute, Asparagus racemosus, Isoprinosine, Shatvari.

\begin{abstract}
The present study was carried out to evaluate the safety of Asparagus racemosus root ethanol extract, isoprinosine and shatvari syrup by acute ad subacute toxicity studies. Acute and subacute oral toxicity study was conducted according to the guidelines of OECD 425 and 407 respectively. In acute oral toxicity, mice were administered with $2000 \mathrm{mg} / \mathrm{kg}$ body weight of ARE, STR and IPR respectively and were observed continuously for the first $4 \mathrm{~h}$ and for the next $24 \mathrm{~h}$ and for the following $48 \mathrm{~h}$ after administration of the test substances. In the subacute toxicity studies, ARE, STR and IPR were given orally at the dose of $2000 \mathrm{mg} / \mathrm{kg}$ body weight daily for 28 consecutive days. General behavior, adverse effects and mortality were observed throughout the experimental period. Food and water intake, body and organ weight variations, hematological and biochemical parameters, histopathological changes were assessed. No mortality or signs of acute toxicity was observed in the mice at the maximum tolerable dose of $2000 \mathrm{mg} / \mathrm{kg}$ body weight. The results did not show any treatment related abnormalities in terms of hematological and biochemical parameters in sub-acute toxicity tests. No significant differences in body weight and organ weight between the control and treated groups were observed. Histopathological analysis showed no morphological changes of the vital organs namely liver and kidney between the control and treated groups. These results concluded that ARE, STR and IPR did not cause any mortality and signs of toxicity at maximum tolerable dose of $2000 \mathrm{mg} / \mathrm{kg}$ body weight in mice.
\end{abstract}

\section{INTRODUCTION}

According to the World Health Organization, $80 \%$ of the remote area population depends on traditional medicine and from time immemorial medicinal plants are used by humans as medicine (WHO, 2000). In primary health care, the uses of medicinal plants as a source of drugs have become popular universally, particularly in developing countries as safe because of natural source (Patwardhan et al., 2004). Herbal remedies

\footnotetext{
* Corresponding Author

Satheesh Kumar Bhandary B., Department of ENT, K. S.Hegde Medical Academy, Nitte University, Mangalore, Karnataka.

Email: satheeshbhandary @ gmail.com
}

being used especially in the form of extracts for the treatment of various diseases is gaining increasing popularity, making them the main stay of health care system, especially among the rural population in the developing countries. In the developing countries, herbal medicines most often are prepared by the traditional herbalists and are used on the basis of traditional knowledge and experience to protect, restore or improve health. The present accepted modern medicine has gradually developed in the recent years by various efforts done by the researchers. However, traditional medicine still remains the basis in the development of new drugs (Tarkang et al., 2012). The review of some medicinal plants clearly validates the effectiveness and reliability of ethno-medical knowledge and traditional uses of these plant species in managing diseases. 
Therefore, this requires mobilizing indigenous healthcare knowledge, empowering traditional healers, and fostering the cooperation between traditional and modern healthcare systems (Butterweck and Nahrstedt, 2012).

Despite the common and frequent use of medicinal plants for therapy, based on the belief that they are safe because they are natural, dosage forms, side effects and efficacy of most of these medicinal plant preparations are usually not clearly defined (Sharma et al., 2001).

In view of developing improved traditional medicines that are affordable, safe, efficient and user friendly or the identification of plant-based drug targets, it is stated that preclinical testing strategies of botanicals should start with the in vivo examination of extracts in relevant animal models to validate the ethnopharmacological/ethnopharmaceutical use.

Asparagus racemosus (family Asparagaceae) also known by the name Shatavari is one of the well known drugs in Ayurveda. It is an important medicinal plant of tropical and subtropical India known to prevent ageing, increase longevity and impart immunity. Reports indicate that the pharmacological activities of $A$. racemosus root extract include anti ulcer, antioxidant, antidiarrhoeal, antidiabetic and immunomodulatory activities (Kamat et al., 2000).

Isoprinosine is an immunostimulator. It has been shown to augment production of cytokines such as IFN- $\gamma$, IL-1and IL-2, increase active $\mathrm{T}$-cell rosettes and induce $\mathrm{T}$-cell surface markers on prothymocytes and also increase proliferation of lymphocytes in response to mitogenic or antigenic stimuli (Patil et al., 2012).

Shatavari syrup is usually prescribed for hormonal regulation and also acts as galactogogue in nursing women. Researchers also noted its long-standing use in traditional ayurveda to support normal digestive function (Gautam et al., 2009).

Based on the traditional knowledge and lack of scientific validation, the present study aimed at evaluating the acute and subacute toxicities of Asparagus racemosus Root Extract, Isoprinosine and Shatavari Syrup in swiss albino mice.

\section{MATERIAL AND METHODS}

The present study was carried out at Central Research Laboratory, K.S Hegde Medical Academy, Deralakatte, Mangalore.

\section{Collection of Plant Material}

Asparagus racemosus roots were collected from Coorg in March 2015 and were identified by Dr. K.R Chandrashekar, Botanist, Department of Applied Botany, Mangalore University, Karnataka (No.MU/AB/222/2016-17).

\section{Preparation of Root Extracts \\ Ethanolic extract}

Asparagus racemosus (AR) roots were dried in hot air oven at $40^{\circ}-50^{\circ} \mathrm{C}$ for a week. The dried roots were powdered using mixer grinder, extracted in soxhlet apparatus with $99 \%$ ethanol for
48 hours. The resulted mixture was evaporated to dryness using a rotary flash evaporator and the condensed extract was stored in refrigerator which was further used for preliminary phytochemical screening following standard procedures.

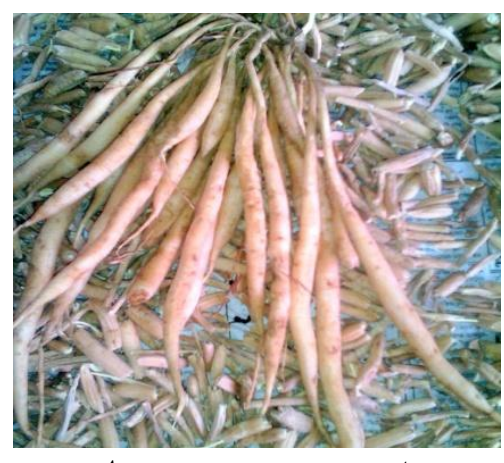

Asparagus racemosus root

\section{Procurement of Isoprinosine and Shatavari syrup}

Isoprinosine tablets (product code: 78/158) were procured from Brandmedicines, European Union. Shatavari syrup was procured from a Himalaya Drug store in Mangalore.

\section{Acute Oral Toxicity \\ Experimental Animals}

Adult female Swiss Albino mice (6-8 weeks old/25-30g) were used for the study(according to OECD guidelines 425) which were procured from the Institutional Animal House, KS Hegde Medical Academy, Nitte University (Ethical Clearance No.115/1999/CPCSEA). The animals were housed under standard animal house conditions and fed with standard laboratory pellets and water ad libitum.

Organization for Economic Co-operation and Development (OECD, 425) guidelines was followed to conduct acute oral toxicity study. Twenty four animals were randomly allocated into four groups of six animals each. Group I (Control): animals were administered orally with vehicle. Remaining groups (II, III and IV) were administered with $2000 \mathrm{mg} / \mathrm{kg}$ body weight of Asparagus racemosus root ethanol extract (ARE), Isoprinosine (IPR) and shatvari syrup (STR) respectively via oral gavage. Doses were prepared using distilled water and dose volume was not more than $1 \mathrm{ml} / 100 \mathrm{~g}$ body weight. Observation was carried out continuously for the first $4 \mathrm{~h}$ and for the next $24 \mathrm{~h}$ and for the following $48 \mathrm{~h}$ after administration of the test substances, for any death or changes in general behavior and other physiological activities (Qazi et al.,2013; Bhandary et al.,2013).

\section{Subacute Oral Toxicity}

Organization for Economic Co-operation and Development (OECD, 407) guidelines was followed to conduct subacute oral toxicity study. Twenty four animals were randomly divided into four groups of six animals each. Group I (C) served as control and received vehicle (distilled water) for 28 days whereas the remaining groups (Group II-ARE, Group III- STR and Group IV-IPR) were orally administered $2000 \mathrm{mg} / \mathrm{kg}$ body weight of 
Asparagus root extract, Shatavari syrup and Isoprinosine daily for 28 consecutive days. Food and water intake were recorded daily, whereas, body weight was recorded once in a week throughout the study period.

\section{Serum isolation and haematology}

At the end of 28 days, the animals were euthanized using chloroform according to CPCSEA guidelines, blood samples were collected from overnight fasted animals through cardiac puncture in plain vials, allowed to stand for 15 minutes and serum was separated by cold centrifugation at $3000 \mathrm{rpm}$ for $10 \mathrm{~min}$. Blood was also collected in ethylene diamine tetra acetic acid (EDTA) coated vials for the analysis of haematological parameters such as white blood cell (WBC) count, red blood cell (RBC) count, haemoglobin $(\mathrm{Hb})$ levels, percentage of lymphocytes (LY), Monocytes (MO), Granulocytes (GR) and Platelet Count (PLT) using Haematology Analyser(ERMA INC.model PCE-210VET).

\section{Serum biochemical parameters}

Serum Glutamate Pyruvate Transaminase (SGPT), Serum

Glutamate Oxaloacetate Transaminase (SGOT), Alkaline phosphatase (ALP), serum albumin, bilirubin, total protein, urea, uric acid and creatinine were analysed using commercially available kits in a semi Autoanalyzer (Model : Rapid Star 21 plus).

\section{Histopathology}

Tissue pieces of vital organs (liver and kidneys) were fixed in $10 \%$ formaldehyde for paraffin histology, processed and stained in hematoxylin and eosin as per the standard protocol. They were observed for possible histopathological changes.

\section{STATISTICAL ANALYSIS}

The data are expressed as Mean \pm SD. Analysis of variance followed by Tukey's multiple comparison test was used for assessing statistical significance between the groups by using Prism 3.0 software. $\mathrm{P}<0.05$ was set as criterion for statistical significance.

\section{RESULTS AND DISCUSSION}

Drugs derived from plant origin are known to play a key role in the management of various chronic diseases and in recent times have received a great preference by researchers as alternative source to allopathic pharmaceutical drugs (Vaghasiya et al.,2011). The herbal products today symbolize safety in contrast to the synthetics that are regarded as unsafe to human and environment.

However, there is a lack of proven scientific studies on the toxicity and safety profile of these treatments in swiss albino mice, the present research was aimed to evaluate the ethanol root extract of A. racemosus (ARE) Isoprinosine (IPR) and Shatavari (STR) syrup for acute and sub-acute toxicity study and to identify the range of dose that could be used for further studies. Prior to toxicity studies, preliminary phytochemical study was carried out to check the presence of various phytochemicals in the extracts and shatavari syrup. The ethanol and aqueous extracts of Asparagus racemosus root revealed the presence of Saponins, Flavonoids, Tannins, free amino acids, Carbohydrate, Vitamin C and sterols. Tannins was present only in the ethanol root extract. Shatavari syrup showed positive test for saponins and carbohydrates. Since the ethanolic root extract showed the presence of more phytoconstituents than the aqueous extract, toxicity evaluation was carried out using ethanolic root extract. The results of preliminary phytochemical screening are shown in Table 1.

Table 1: Qualitative Phytochemical Screening.

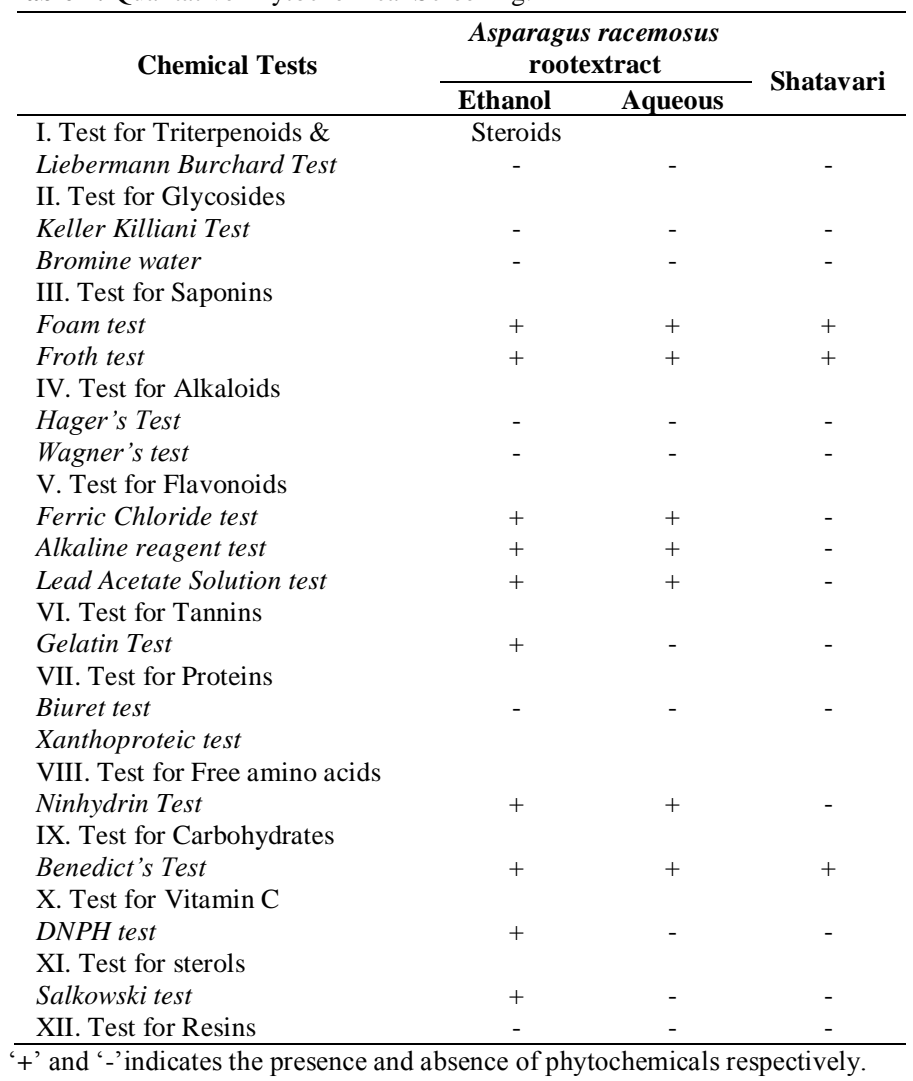

The oral acute toxicity study of ARE, IPR and STR was carried out in swiss albino mice at single dose of $2000 \mathrm{mg} / \mathrm{kg}$ body weight and was continuously monitored for first 4 hours, followed for a period of 72 hours for any toxic signs and symptoms after the treatment period. In all the treated groups, no behavioural changes were found within first four hours of ARE, STR and IPR (2000 $\mathrm{mg} / \mathrm{kg}$ body weight) administration during cage side observations. After 24 to $48 \mathrm{~h}$ there was no mortality recorded in the experimental groups. Any pharmaceutical compound or drug with the oral $\mathrm{LD}_{50}$ higher than $1000 \mathrm{mg} / \mathrm{kg}$ could be considered safe and non toxic (Mythilypriya et al., 2007). This suggests that ARE, IPR and STR is practically non-toxic at single dose level of 2000 $\mathrm{mg} / \mathrm{kg}$ body weight. However in case of multiple dose uses in the treatment of the chronic diseases, whether it will be safe without any effect on relative organ weight, hematological and 
biochemical parameters can be confirmed from its subacute toxicity study. Therefore a sub-acute toxicity study was carried out with dose of $2000 \mathrm{mg} / \mathrm{kg}$ body weight of the test substances as per OECD guidelines (Kunimatsu et al., 2004). Body weight changes are associated with toxic effects of chemicals and drugs. However, it is confirmed by scientific evidence that changes in the body weights are accompanied with accumulation of fat and physiological adaptation responses to the plant extracts rather than to the toxic effects of chemicals or drugs that lead to decreased appetite and, hence lower caloric intake by the animal (Kifayatullah et al., 2014). ARE, STR and IPR groups did not record any significant alterations in body weight gain compared to Control (C) (Table 2). Further, there were no changes in food and water intake of ARE, STR and IPR compared to Control.

Table 2: Effect of ARE, STR and IPR subacute oral administration on Body Weight in Swiss Albino Mice.

\begin{tabular}{ccc}
\hline Groups & $\begin{array}{c}\text { Initial Body } \\
\text { Weight(g) }\end{array}$ & Final Body Weight(g) \\
\hline Control & $23.75 \pm 1.26$ & $24.5 \pm 1.16$ \\
ARE & $24.2 \pm 1.43$ & $24.6 \pm 1.28$ \\
STR & $23.83 \pm 1.19$ & $25.2 \pm 1.08$ \\
IPR & $24.96 \pm 1.18$ & $25.4 \pm 1.42$ \\
\hline
\end{tabular}

Table 3: Effect of ARE, IPR and STR subacute oral administration on Organ weights in Swiss Albino Mice.

\begin{tabular}{lcccc}
\hline Organs & Control & $\begin{array}{c}\text { Groups } \\
\text { ARE }\end{array}$ & IPR & STR \\
\hline Liver & $1.24 \pm 0.09$ & $1.30 \pm 0.05$ & $1.30 \pm 0.14$ & $1.32 \pm 0.12$ \\
Kidney & $0.40 \pm 0.03$ & $0.45 \pm 0.04$ & $0.39 \pm 0.06$ & $0.39 \pm 0.05$ \\
Spleen & $0.11 \pm 0.01$ & $0.12 \pm 0.01$ & $0.12 \pm 0.02$ & $0.10 \pm 0.01$ \\
Thymus & $0.22 \pm 0.05$ & $0.24 \pm 0.04$ & $0.26 \pm 0.03$ & $0.18 \pm 0.04$ \\
\hline
\end{tabular}

A statistically non-significant difference $(\mathrm{P}>0.05)$ of the relative weight of the vital organs like liver, kidney, spleen and thymus were found in both control and treated group indicating no toxic effect of the test substances (Table 3). These data provides support for the safety of ARE, IPR and STR.
The hematological parameters of experimental groups showed no significant difference $(\mathrm{P}>0.05)$ when compared to control group (Fig.1-7). Many scientific evidences stated that some phytochemicals isolated from plants affect red blood cell levels which are produced from bone marrow (Sairam et al., 2003). The results of the hematological parameters indicate that, the test substances may not have harmful effects on bone marrow function and justify the fact that at the highest dose, ARE, IPR and STR does not induce anaemia making it safe. Similarly, estimation of serum biochemical parameters in treated mice showed nonsignificant differences $(\mathrm{P}>0.05)$ compared to control group (Fig.817).

Transaminases such as Aspartate and alanine aminotransferase are distinguished indicator of liver function and used as biomarkers to conclude the possible toxicity of drugs and xenobiotics (Adeneye and Olagunju, 2009).Normally, destruction to the hepatic parenchymal cells will result in an increase of both these enzymes in the blood (Donkor et al.,2014). There were no changes in the SGPT and SGOT levels, which divulge that the extract did not affect the liver function or metabolism. Distorted liver functions are indicated by elevated bilirubin levels and a small rise is an important marker of liver damage in experimental animals.

Determination of plasma proteins like albumin is required in order to assess the synthetic capacity of the liver and reduction in plasma proteins therefore have a tendency to reveal persistent damage (Rahman et al.,2000). No significant differences in the levels of SGPT, SGOT, bilirubin and total protein were observed between the control and treated groups. This indicates that ARE, IPR and STR did not cause any damage to the liver.

Kidney parameters such as blood urea nitrogen (BUN), creatinine, urea and uric acid were within normal range as similar to control group suggesting that sub-acute administration of ARE, IPR and STR did not cause any damage to the kidney.

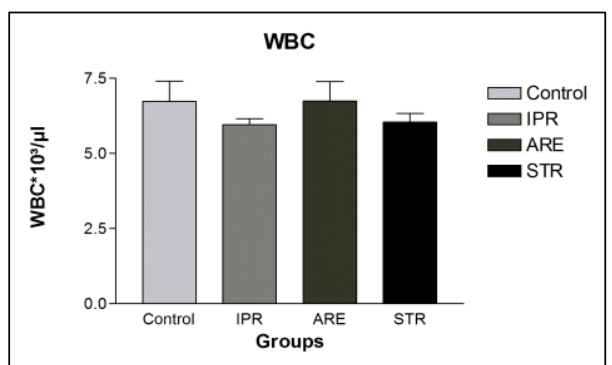

Fig No. 1

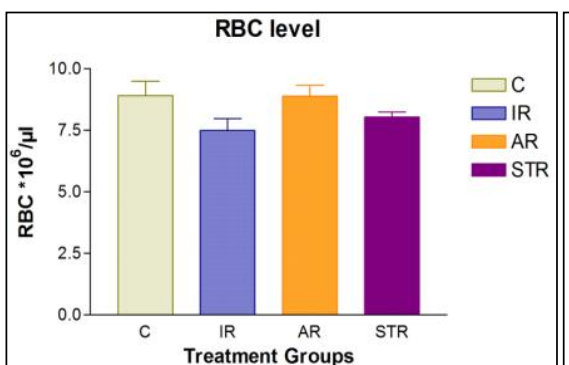

Fig No.2

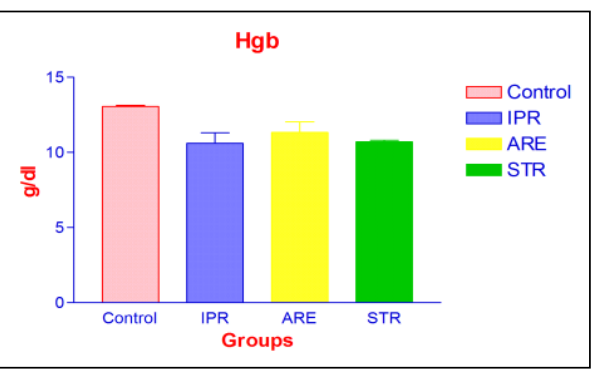

Fig No.3 


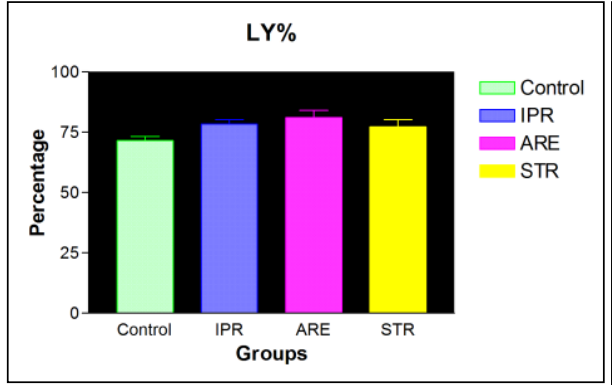

Fig No.4

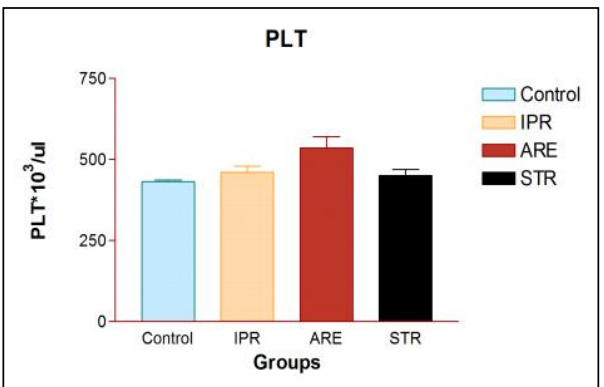

Fig No.7

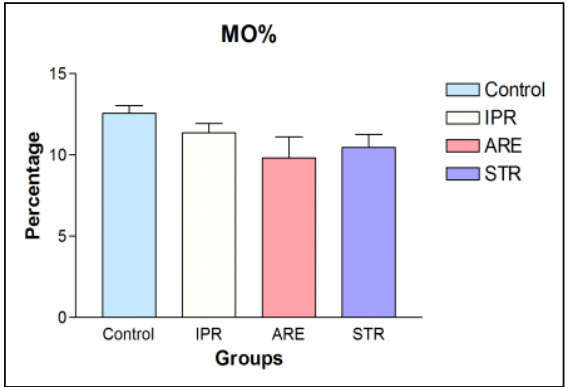

Fig No.5

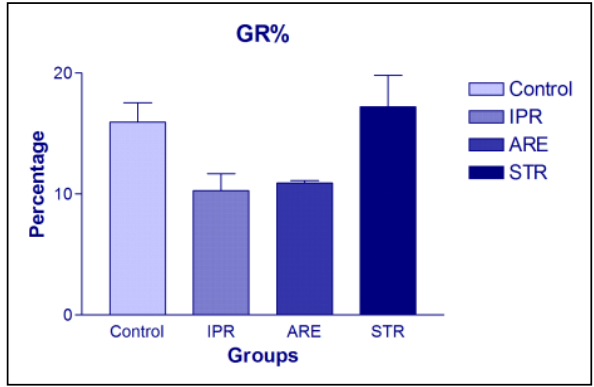

Fig No.6

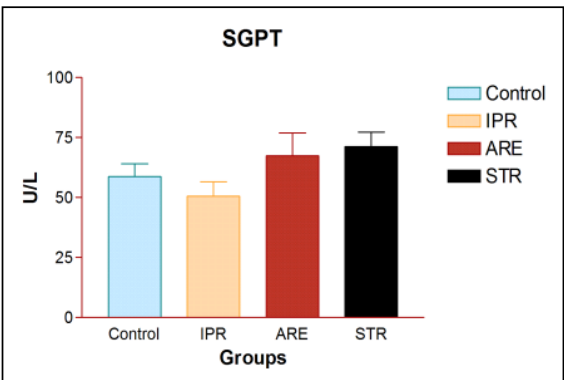

Fig No.8

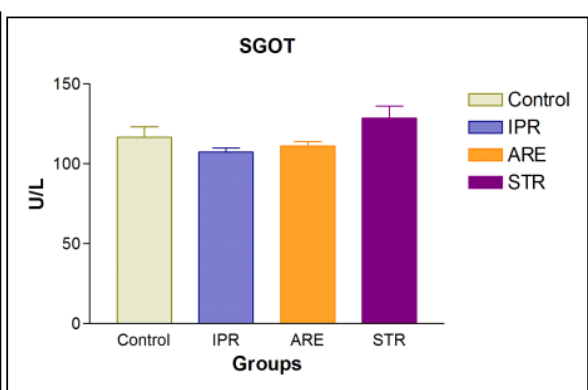

Fig No.9

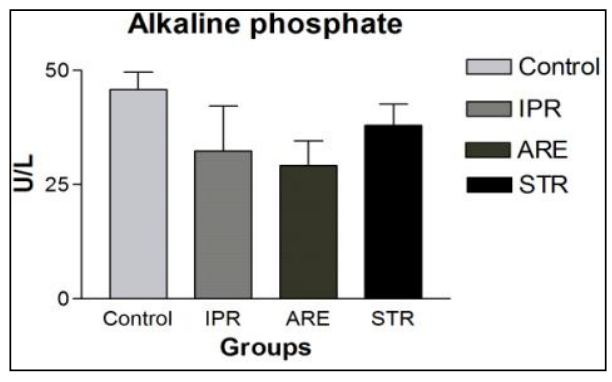

Fig No.10

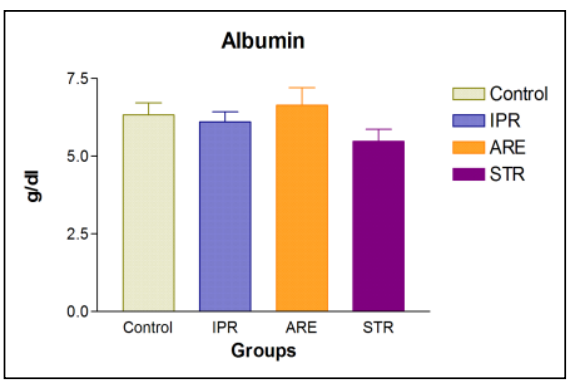

Fig No.11

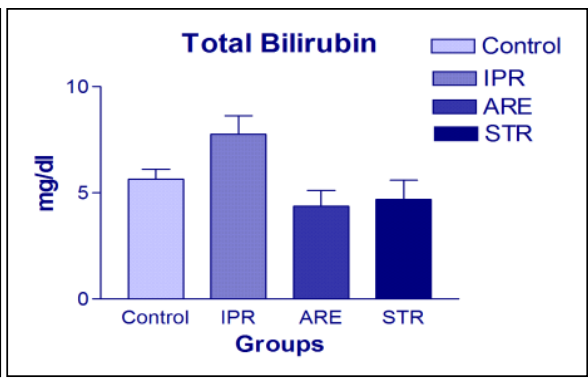

Fig No.12

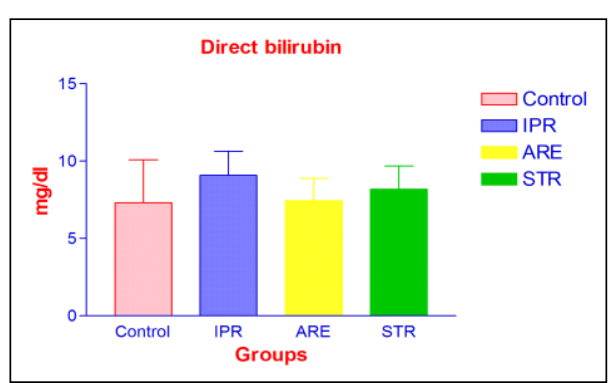

Fig No.13

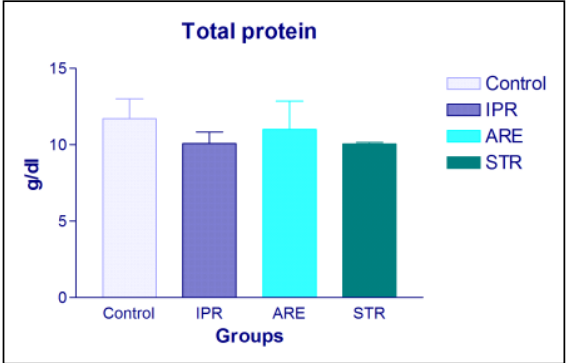

Fig No.14

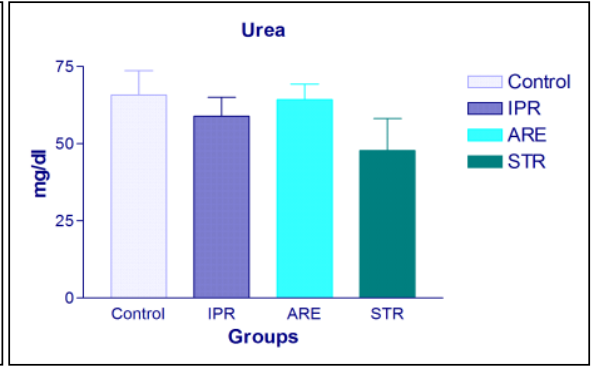

Fig No.15

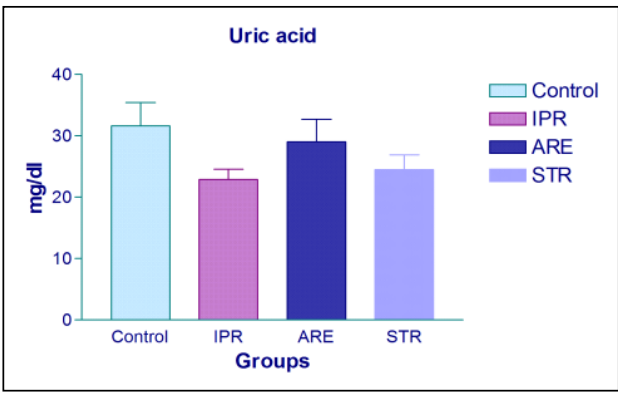

Fig No.16

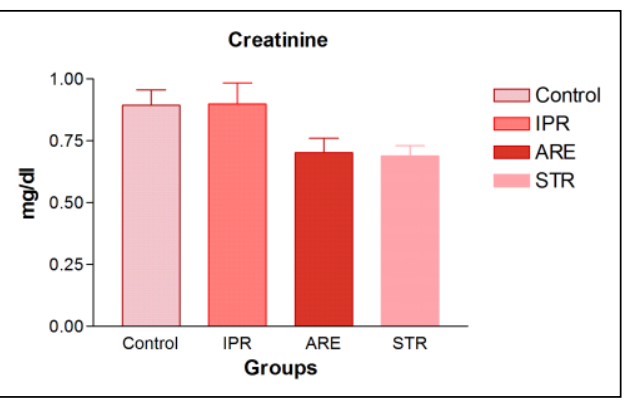

Fig No.17 
Liver:

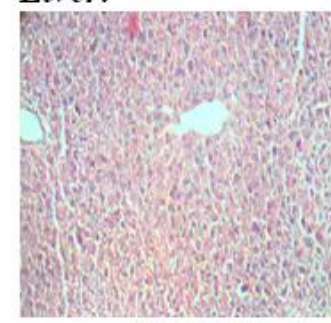

Control(A)

Kidney:

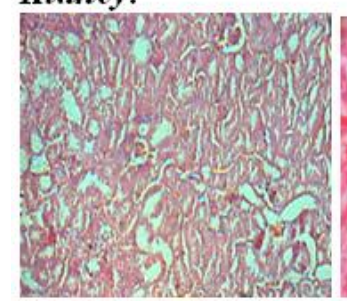

Control(E)

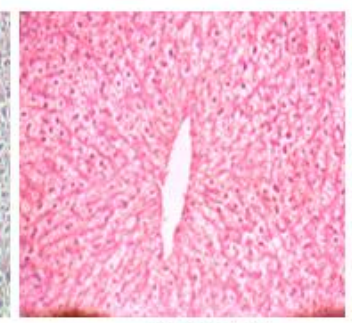

$\operatorname{ARE}(B)$

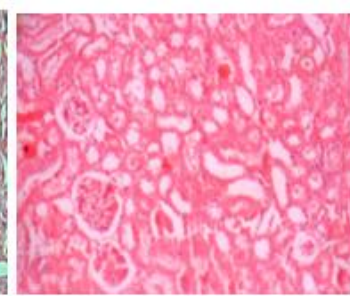

$\operatorname{ARE}(\mathbf{F})$

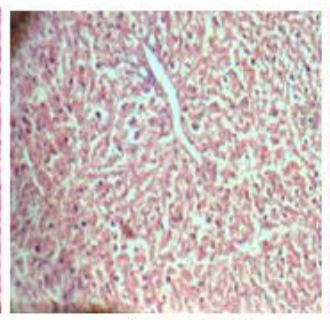

IPR(C)

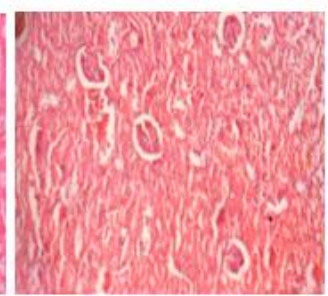

IPR(G)

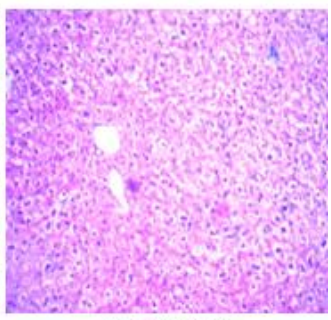

STR(D)

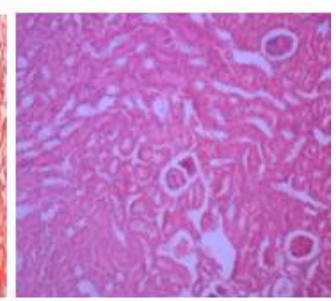

STR(H)
Histopathological studies provide supportive evidence for biochemical and haematological observations (Wolf et al., 2008). Histopathological features of control and treated mice revealed the absence of pathological lesion in kidney and liver.

Histoarchitecture of control, liver and kidney of ARE, STR and IPR treated mice at $2000 \mathrm{mg} / \mathrm{kg}$ b.wt (A-H).

Since there were no signs of toxicity with respect to body weight, organ weight, haematology, biochemistry and histopathological examination as observed in all the experimental groups, it can be inferred that ARE, IPR and STR will not produce any toxicity. Based on the obtained results, the No Observed Adverse Effect Level (NOAEL) of ARE, IPR and STR is greater than $2000 \mathrm{mg} / \mathrm{kg}$ body weight.

\section{CONCLUSION}

The present study demonstrated that the Asparagus racemosus root ethanolic extract (ARE), Isoprinosine (IPR) and Shatvari (STR) syrup did not produce any toxic signs or evident symptoms at acute and sub-acute oral toxicity. ARE, IPR and STR did not cause any lethality nor produced any remarkable histopathological signs or biochemical alteration. The results support the reliable safety profile of ARE, IPR and STR in Swiss albino mice offering no obvious toxicity and opening promising alternatives in exploring therapeutic interest of Asparagus racemosus root ethanolic extract, Isoprinosine and Shatvari syrup with reduction of possible adverse effects.

\section{ACKNOWLEDGEMENT}

The authors acknowledge Nitte University for providing laboratory facilities and also would like thank Dr. K.R Chandrashekar, Chairman, Department of Applied Botany,
Mangalore University, Karnataka, India for the identification of study plant.

Financial support and sponsorship: The authors would like to extend sincere gratitude to the Board of Research in Nuclear Sciences, Department of Atomic Energy, Government of India for the financial support (Sanction No. 34(1)/14/32/2014-BRNS).

Conflict of Interests: There are no conflicts of interest.

\section{REFERENCES}

Adeneye AA, Olagunju JA. Preliminary hypoglycemic and hypolipidemic activities of the aqueous seed extract of Carica papaya Linn in Wistar rats. Biol Med 2009; 1(1): 1-10.

Tarkang PA, Okalebo FA, Agbor GA, Tsabang N, Guantai AN, Rukunga GM. Indigenous Knowledge and folk use of a polyherbal antimalarial by the Bayang Community, South West Region of Cameroon. J. Nat. Prod. Plant Resour, 2012; 2 (3):372-380.

Butterweck V and Nahrstedt A. What Is the Best Strategy for Preclinical Testing of Botanicals? A Critical Perspective. Planta Med, 2012; 78: 747-754.

Donkor K, Okine LNK, Abotsi WKM, Woode E. Acute and subchronic toxicity studies of aqueous extract of root bark of Cassia sieberiana DC in rodents. J Appl Pharm Sci 2014; http:// dx.doi.org/10.7324/JAPS.2014.40415.

Gautam M, Saha S, Bani S, Kaul A, Mishra S, Patil D, Satti NK, Suri KA, Gairola S, Suresh K, Jadhav S, Qazi GN, Patwardhan B. Immunomodulatory activity of Asparagus racemosus on systemic Th1/Th2 immunity: Implications for immunoadjuvant potential. Journal of Ethnopharmacology 2009; 121: 241-247.

Kamat JP, Boloor KK, Devasagayam TP, Venkatachalam SR. Antioxidant properties of Asparagus racemosus against damage induced by gamma radiation on rat liver mitochondria. J Ethanopharmacol, 2000; 71: $425-435$

Kifayatullah M, Waheed I, Das SK, Sisugoswomi M, Izharullah. Evaluation of hydroethanolic extract of Opuntia monacantha Haw for analgesic activity. World J Pharm Pharm Sci, 2014; 3(2): 100620. 
Kunimatsu T, Yamada T, Miyata K, Yabushita S, Seki T, Okuno Y, et al. Evaluation for reliability and feasibility of the draft protocol for the enhanced rat 28-day subacute study (OECD Guideline 407) using androgen antagonist flutamide. Toxicology, 2004; 200 (1): $77-$ 89.

Mythilypriya R, Shanthi P, Sachdanandam P. Oral acute and subacute toxicity studies with Kalpaamruthaa, a modified indigenous preparation, on rats. J Health Sci, 2007; 53(4): 351-8.

Patil US, Jaydeokar AV, Bandawane DD. Immunomodulators: A Pharmacological Review. International Journal of Pharmacy and Pharmaceutical Sciences, 2012; 4(1):30-36

.Patwardhan B, Vaidya ADB, Chorghade M. Ayurveda and natural products drug discovery. Current Science, 2004; 86(6): 25.

Qazi NS, Qayyum R, Waheed A. Acute and chronic toxicity study of ethyl acetate fraction of Caralluma tuberculata in mice. International Journal of Pharmacology and Clinical Sciences, 2013; 2 (4):99-104.

Rahman MF, Siddiqui MK, Jamil K. Effects of Vepacide (Azadirachta indica) on aspartate and alanine aminotransferase profiles in a sub chronic study with rats. Journal of Human and Experimental Toxicology. 2000; 20:243-249.

Sairam KS, Priyambada NC, Goel RK. Gastroduodenal ulcerprotective activity of Asparagus racemosus. An experimental, biochemical and histological study. J Ethnopharmacol 2003; 86(1): 1-10.

Satheesh Kumar Bhandary B, Sharmila KP, Suchetha Kumari N, Vadisha Bhat S. Acute and subacute toxicity study of the ethanol extracts of Punica granatum (linn). Whole fruit and seeds and synthetic ellagic acid in swiss albino mice. Asian J pharm clin res, 2013; 6 (4):192198.
Sharma PV, Charaka S. 2001. Chaukhambha orientalis. Varanasi. India: 7-14.

Vaghasiya YK, Shukla VJ, Chanda S. Acute oral toxicity study of Pluchea arguta Boiss extract in mice. J Pharmacol Toxicol 2011; 6(2): 113-23.

WHO. General Guidelines for Methodologies on Research and Evaluation of Traditional Medicine.WHO/EDM/TRM/2000;1.

Wolf PL, Williams D, Tsudaka T, Acosta L.1972.Methods and Techniques in Clinical Chemistry. USA : John Wiley \& Sons.

\section{How to cite this article:}

Bhandary BSK, Sharmila KP, Kumari NS, Bhat VS, Fernandes R. Acute and Subacute Toxicity Profile of Asparagus racemosus root extract, Isoprinosine and Shatvari Syrup in Swiss Albino Mice. J App Pharm Sci, 2017; 7 (05): 129-135. 